Al-Azhar Bull. Sci. Vol. 24, No. 2 (Dec.): pp. 1-15, 2013.

\title{
IMPROVING GROWTH, YIELD QUALITY AND CHEMICAL CONSTITUENTS OF SESAME PLANTS BY FOLIAR APPLICATION OF ASCORBIC ACID, BENZYL ADENINE AND PACLOBUTRAZOL
}

EMAD EL- DEIN A. EWAIS, ABD EL-MONEM M. SHARAF, ESAM A. ABD EL-AZIM, MOHAMED A. ISMAIL AND MOHAMED A. AMIN

Botany and Microbiology Department, Faculty of Science, Al-Azhar University, Cairo, Egypt.

\begin{abstract}
The effect of ascorbic acid (50 and $100 \mathrm{ppm}$ ), benzyl adenine (50 and $100 \mathrm{ppm})$ and paclobutrazol (25 and $50 \mathrm{ppm}$ ) foliar application on growth, yield and some physiological parameters of sesame (Sesamum indicum var. Shandawil 3) plants were determined. All treatments caused a great improvement in growth parameters (shoot height, root lengths and number of leaves as well as fresh and dry weights of shoots and roots) of the developed plants. Paclobutrazol was more effective than other treatments in enhancing chlorophyll contents and carotenoid content. The results also showed that nearly all of the treatments tended to increase total soluble carbohydrates and protein contents in sesame plants. The changes in proteolytic, amylolytic and lipolytic activities were also recorded. This was associated by improving yield quality and the nutritional value of the seeds. The effect of paclobutrazol was superior to that of ascorbic acid, benzyl adenine on increasing yield components. The percentage of the highest lipid was recorded by $50 \mathrm{ppm}$ of ascorbic acid, whereas the highest carbohydrates and proteins of the yielded seeds were observed with plants treated with $100 \mathrm{ppm}$ benzyl adenine.
\end{abstract}

\section{Introduction}

Sesame (Sesamum indicum L.) is one of the most ancient oilseed crops used by man and is cultivated extensively from tropical to temperate regions of the world (Weiss 1971). Sesame is one of the most important oilseed crops worldwide, uses as a traditional health food. Sesame seeds are used in the making of tahini (sesame butter) and halva, and for the preparation of rolls, crackers, cakes and pastry products in commercial bakeries (Nzikou et al. 2009). Shalaby et al. (2005) clearly indicated that plant growth retardants significantly affected growth parameters of sesame plants (Sesamum indicum). It could be seen that foliar application with 20 $\mathrm{mg} / \mathrm{L}$ uniconazole caused significant stimulatory effect on plant height, number of branches, leaves and capsules/plant, dry weight of stem + branches, leaves and capsules/plant compared with control. Also, revealed that treatment with uniconazole (20 and $30 \mathrm{mg} / \mathrm{L}$.) to sesame plants caused significant effect on sesame leaves photosynthetic pigments content. Foliar application with $20 \mathrm{mg} / \mathrm{L}$. uniconazole caused significant stimulatory effect on photosynthetic pigment contents compared with control and $30 \mathrm{mg} / \mathrm{L}$. uniconazole. Growth regulators and vitamins are known to affect plant growth through primary and secondary metabolism (Ewais et al. 2003 and Reda et al. 2007). Rafique et al. (2011) showed 
the best results on seedling growth, fresh and dry matter production of pumpkin seedlings due to $30 \mathrm{mg} \mathrm{L}^{-1}$ ascorbic acid treatments. Seedlings fresh weight, protein contents, protease and nitrate reductase activities were significantly affected by 30 $\mathrm{mg} \mathrm{L}^{-1}$ ascorbic acid. Moreover, Mazheret al. (2011) found stimulatory effect of ascorbic acid (100 and $200 \mathrm{ppm}$ ) on all growth parameters (plant height, number of branches, number of leaves, stem diameter, root length as well as fresh and dry weights of all plant organs) of Codiaeum variegatum $\mathrm{L}$.

Several researchers, mentioned that benzyl adenine (BA) improve vegetative growth and yield quality, such as Mazrou (1992) on datura, Menesi et al. (1994) on Tagetes erecta, Zinna elegans and Celusia argentia, Farahat et al. (2002) on fennels, Vijay and Laxmi (2001) on mungbean, El-Abagy et al. (2003) on faba bean. ElMaadawy et al. (2006) indicated that treating pot marigold plants with BA at 100 ppm gave the highest number of inflorescences, which was significantly higher than the control in both seasons. Different benzyl adenine concentrations significantly increased inflorescence diameter, compared to control. Spraying plants with BA had also generally favorable effect on fresh and dry weight of inflorescences as compared to unsprayed plants. Other investigators; Zedan (2000) working on Coriander and Zhang et al. (2006) working on soybean observed that paclobutrazol treatments caused significant reductions in plant height, internodes length, leaf length and leaf area/plant, while dry weight per plant was increased.

Therefore, the aim of this study was auggested to increase Sesamum indicum productivity and promote beneficial effects on growth by the application of ascorbic acid (Asc), benzyl adenine (BA) and paclobutrazol (Pac).

\section{Materials and Methods}

Seeds of sesame "Sesamum indicum" (Shandawil 3) was obtained from Agricultural Research Centre, Ministry of Agriculture, Giza, Egypt. Uniform sesame seeds were planted in natural loamy soil conditions in Botanical garden, Botany and Microbiology Dept., Fac. of Sci., Al- Azhar Univ., Nasr City, Cairo, Egypt, in a plot (4 $\mathrm{m}$ width and $15 \mathrm{~m}$. length) containing 7 groups representing the following treatments: Ascorbic acid at $50 \mathrm{ppm}$ and $100 \mathrm{ppm}$ were applied to the $2^{\text {nd }}$ and $3^{\text {rd }}$ groups, respectively; benzyl adenine at 50ppm and $100 \mathrm{ppm}$ were applied to the $4^{\text {th }}$ and $5^{\text {th }}$ groups, respectively. The $6^{\text {th }}$ and $7^{\text {th }}$ groups were treated with paclobutrazol at 25 and 50ppm, respectively. The first group was left aside untreated serving as control. The seeds were sown on one side of the ridge, with $20 \mathrm{~cm}$ apart between the hills. The developed plants were irrigated whenever required. Concentrations of the used plant growth regulators and vitamin $\mathrm{C}$ were chosen according to a preliminary 
experiment in which they caused a maximum germination percentage. The plants were sprayed twice with the above mentioned treatments, the first and second was added at 33 and 65 days of plant age respectively. The plant samples were collected for analysis when the plants were 40 (Stage I) and 72 (Stage II) days old. At the end of the growth season, analysis of the seeds yielded from the different treatments and the control were done. Chlorophylls contents of were estimated using the method of Vernon and Selly (1966). Carotenoids contents of were estimated according to Lichtentahler (1981). soluble carbohydrates were measured according to the method of Umbriet et al. (1969). Contents of soluble proteins were estimated according to the methods of lowery et al. (1951). Activities of amylases were determined using the method of Afifi et al. (1986). Proteases activities were estimated using the method of Ong and Guacher (1972). Lipase activities were determined by method of Elwan et al. (1976).Total lipids were determined by using a soxhlet apparatus according to Guenther (1972). Statistical analysis of the obtained results were done using (L.S.D.) according to Snedecor and Cochran (1982).

\section{Results and Discussion}

\section{Growth parameters}

The obtained results (Tables 1 ) revealed that application of ascorbic acid or benzyl adenine at 50 and $100 \mathrm{ppm}$ and paclobutrazol at 25 and $50 \mathrm{ppm}$ showed significant improvement effects on growth parameters of sesame plants in most cases. These effects were clear with the resulted induced increases in shoot heights and root lengths and number of leaves/plant. Benzyl adenine was more effective than other treatments in enhancing shoot lengths during the two stages. These findings are in accordance with Ibrahim et al. (2010) who found that foliar application of benzyl adenine (BA) at (50, 100 and $150 \mathrm{ppm})$ were significantly affected on croton plant height and number of branches. This may be as a result of its role in the regulation of many aspects of growth and differentiation including cell division, apical dominance, nutrient mobilization, chloroplast development, senescence and flowering (Binns 1994, and Hare et al. 1997).

Moreover, paclobutrazol was most effective in enhancing root lengths and number of leaves during stage I. These results are in harmony with those reported by Chaturvedi et al. (2009) who found significant increment in root length of Saussurea costus (Falc) seedlings at treatment with 25, 50, $100 \mathrm{ppm}$ of paclobutrazol.

The obtained results (Tables 2) revealed that application of ascorbic acid at 50 or benzyl adenine at 50 and $100 \mathrm{ppm}$ and paclobutrazol at 25 and $50 \mathrm{ppm}$ created 
significant increases in fresh and dry weight of shoots and roots of sesame plants. These findings are in accordance with Ewais (2003) who reported that application of ascorbic acid improved growth and yield characteristics of broad bean plants. Recently, Rafique et al. (2011) found that the best results on seedling growth, fresh and dry matter production of pumpkin seedlings resulted by $30 \mathrm{mg} \mathrm{L}^{-1}$ ascorbic acid treatments. With respect to benzyl adenine, many investigators obtained similar positive effects on the growth of other plants such as mungbean (Vijay and Laxmi 2001); faba bean (El-Abagy et al. 2003) marigold (El-Maadawy et al. 2006a). Also, Ibrahim et al. (2010) found that foliar application of benzyl adenine (BA) at 50, 100 and $150 \mathrm{ppm}$ were significantly affected on croton plant height, number of branches and leaves/plant, root length, leaf area and fresh and dry weights of stem, leaves and roots.

\section{2- Photosynthetic Pigments:}

The contents of chlorophyll $a$; $b$; total chlorophyll $(a+b)$ and carotenoids of sesame plants (Table 3) showed, consistent and gradual decreases in response to various treatments applied of Asc and BA at all doses. The obtained results agree with those observed by a number of investigators for example, El-Maadawy et al. (2006) who observed that the lowest BA concentration (50 ppm) caused a decrease in the total chlorophyll content of Calendula afficinalis L. plants compared with that of untreated plants. On the contrary, the obtained results showed that Paclobutrazol at $25 \mathrm{ppm}$ was more effective than other treatments in enhancing chlorophyll contents and carotenoid content at stage II while, at stage I it was found that Paclobutrazol at $50 \mathrm{ppm}$ was more effective. The obtained results agree with those observed by Hamza et al. 2007 who recorded that treating plants of Pelargonium zonale with paclobutrazol significantly increased the total chlorophyll content when compared with the untreated control plants.

\section{3- . Soluble Carbohydrates:}

Results of the present work (Table 4) revealed that total soluble carbohydrates contents of sesame plants were tended to increase, with some exceptions, in response to the treatment with ascorbic acid, benzyl adenine and paclobutrazol at all doses. In agreement with these results a number of investigators observed stimulating effect regarding the effect of ascorbic acid (Abdel Aziz et al. 2006; Farahat et al. 2007and Eid et al. 2010), benzyl adenine (Youssef 2004a) or paclobutrazol (Amin 2007 and Hamza et al. 2007) on carbohydrate contents. On the

other hand, Elgayar (2004) revealed that treatment of soybean with benzyl adenine (25 and $50 \mathrm{ppm}$ ) resulted in slight effects on carbohydrate. On the contrary, El- 
Abagy et al. (2003) found that spraying faba bean plants with benzyl adenine (25 and $50 \mathrm{ppm}$ ) decreased carbohydrate percentage content.

\section{4- Soluble Proteins:}

In the present study, it was found (Table 5) that protein contents in roots and fruits of sesame plants, mostly, were significantly decreased in response to all doses applied of ascorbic acid, benzyl adenine and paclobutrazol. On the contrary ElAbagy et al. (2003) cleared that spraying faba bean plants with benzyl adenine significantly increased crude protein content.

On the other hand, application of $50 \mathrm{ppm}$ Asc at both stages I\& II; $100 \mathrm{ppm}$ Asc during first stage and 50 or $100 \mathrm{ppm}$ benzyl adenine during two stage and $50 \mathrm{ppm}$ paclobutrazol at stage I caused significant increases in soluble protein contents of sesame shoot. These obtained results are in harmony with those reported by AbdelHalim (1995) who observed that ascorbic acid increased protein content of wheat grains; El-Abagy et al. (2003) who found that spraying faba bean plants with benzyl adenine significantly increased crude protein content and Wanas (2007) indicated that application of paclobutrazol considerably increased the levels of crude protein in leaves of treated faba bean plants compared with those of untreated ones.

\section{5- Enzymes Activities:}

The obtained data (Table 6) indicated that both applied doses of ascorbic acid (Asc), benzyl adenine (BA) and paclobutrazol (Pac), significant increased the activities of proteases at stage I of plant growth. The same results appeared at stage II with only Asc. The most proteases activities were recorded by Pac at $25 \mathrm{ppm}$ (stage I), Asc $100 \mathrm{ppm}$ at stage II. The stimulating effect of ascorbic acid on protease activity, obtained in the present study, are harmony with those observed by Rafique et al.(2011) who found that protease activity was higher in pumpkin seedling from seeds treated with $15 \mathrm{mgL}^{-1}$ Asc.

Concerning the activities of amylases, results in table (6) indicated that foliar application of Asc, BA and Pac caused, with one exception case, significant increases at stage II. In this respect, Husein (1993) showed that the activities of amylases in Datura plants were significantly increased as a result of treatments with benzyl adenine. The exceptional case was represented by significant decreased in the activity of amylase at stage II in response to BA at $100 \mathrm{ppm}$.

Results in table (6) also, indicated that foliar application of Asc, BA and Pac resulted, with two exception cases, significantly increased (at stage I). The exceptional cases were represented by significant decreases in proteases at stage I in 
responses to $50 \mathrm{ppm}$ of Asc and Pac at $50 \mathrm{ppm}$. In this regard, Prusakova et al. (2004) reported a similar view that the growth retarding activity of triazole compounds such as paclobutrazol appears in the inhibition of amylase activity in barley (Hordium vulgare L.).

It was also observed (Table 6) that $100 \mathrm{ppm}$ of BA at both stages of growth and 50 and $100 \mathrm{ppm}$ of Asc at stage II caused significant increases in the lipolitic activities of sesame plants. In this regard, Dowiadar et al. (1996) working on Raphanus sativus plants, reported that the increase in the activity of all hydrolytic enzyme and $\beta$ amylases were run parallel to the increase in soluble sugars. In the contrary, the obtained results showed that BA and Pac at 50 ppm during stages I\& II; 50 and $100 \mathrm{ppm}$ Asc at stage I and $25 \mathrm{ppm}$ Pac at stage II caused significant decreases of these activities.

\section{6- Yield components and nutritional value of the yielded seeds:}

Results recorded in table (7) indicated that foliar application of ascorbic acid (Asc), benzyl adenine (BA) and paclobutrazol (Pac) caused significant increases in yield components of sesame plants. The highest value of all yield were obtained with the plants that treated with Pac $(50 \mathrm{ppm})$. The sequence of increase in number and weight of fruits/plant and weight of 1000 seeds was as follows Pac > BA >Asc. The increments of weight of 1000 seeds estimated by $36.71 \%, 20.57 \%$ and $17.41 \%$ in response to treating with Pac, BA and Asc, respectively compared with the control plants. Paclobutrazol showed better stimulation on yield components than other treatments. In this connection, Nassar et al. (2001) working on sweet paper, mentioned that Pac application at 10-30 ppm reduced plant height and increased number of flowers/plant, Abdul Galeel et al. (2007) reported that the application of Pac on Catharanthus roseus had significant effects on photosynthetic and anatomical responses thus can be used for improving productivity in medicinal plants. Moreover, Lolaei et al. (2012) reported that the highest leaf number, leaf area, petiole length, and total soluble solid percent were observed in control plants, while highest fruit number, fruit weight, fruit set, flower number and yield of strawberry were obtained in plants treated with $90 \mathrm{mg} \mathrm{L}^{-1}$ Pac. They also mentioned that foliar application of Pac prior to flowering is recommended to increase the yield of strawberry.

The obtained results (Table 8) showed that Asc, BA and Pac significantly increased carbohydrates contents and total lipids of the yielded seeds for most cases. 
It was also observed that applied Asc (50 ppm) and BA (100 ppm) tended to significant increases in proteins contents of the yielded seeds. The increases in the contents of total lipid \% of the seeds yield were shown to be the following order: Asc > Pac > BA. In this regard, Vasudevan et al. (1996) reported that spraying three sunflower cultivars with cytokinin produced the highest seed oil content. Talaat and Youssef (1998) showed that oil in seeds of rosella plants were significantly increased as a result of BA application, especially at $40 \mathrm{mg} / \mathrm{L}$. Abed (2001) observed that BA significantly increased oil and protein $\%$ in seeds of cotton plants. Ibrahim et al. (2001) found that treatment of sunflower plants with kinetin $50 \mathrm{ppm}$ gave a significant increase in crude fat $\%$, respectively. Yousif et al. (2012) observed that $0.5 \mathrm{~g} \mathrm{l}^{-1}$ sucrose plus $150 \mathrm{~g}^{-1}$ ascorbic acid increased fresh and dry weight, and total carbohydrates contents in snapdragon cut spike flowers.

In conclusion, from the bulk of data obtained in the present investigation, it can be recommended that foliar applications of ascorbic acid, benzyl adenine and paclobutrazol had a beneficial effect on growth and chemical constituents and caused high yield quality of sesame plants.

Table (1): Effect of ascorbic acid (Asc), benzyl adenine (BA) and paclobutrazol (Pac) on shoot length, root length and number of leaves of sesame Sesamum indicum (var. Shandawil 3) plants. Values given are means of ten replicates.

\begin{tabular}{|l|l|l|l|l|l|l|}
\hline \multirow{2}{*}{$\begin{array}{l}\text { Treatment } \\
\text { ppm) }\end{array}$} & \multicolumn{2}{|c|}{ Shoot length $(\mathrm{cm})$} & \multicolumn{2}{c|}{ Root length $(\mathrm{cm})$} & \multicolumn{2}{c|}{ Number of leaves } \\
\cline { 2 - 7 } & Stage I & Stage II & Stage I & Stage II & Stage I & Stage II \\
\hline Control & 35.20 & 120.39 & 12.80 & 21.59 & 13.60 & 46.00 \\
\hline Asc 50 & 38.20 & 145.60 & 15.90 & 21.40 & 15.30 & 51.20 \\
\hline Asc 100 & 26.40 & 127.80 & 11.40 & 16.90 & 14.40 & 43.80 \\
\hline BA 50 & 48.50 & 146.40 & 14.70 & 18.50 & 17.00 & 69.20 \\
\hline BA 100 & 37.70 & 144.40 & 12.90 & 19.86 & 13.00 & 55.00 \\
\hline Pac 25 & 43.10 & 128.06 & 16.00 & 17.22 & 17.30 & 54.40 \\
\hline Pac 50 & 40.50 & 128.90 & 15.60 & 15.30 & 15.90 & 54.20 \\
\hline LSD at 0.05 & $\mathbf{0 . 9 1}$ & $\mathbf{1 . 7 4}$ & $\mathbf{0 . 5 2}$ & $\mathbf{0 . 7 4}$ & $\mathbf{0 . 4 2}$ & $\mathbf{1 . 7 4}$ \\
\hline
\end{tabular}


Table (2): Effect of ascorbic acid (Asc), benzyl adenine (BA) and paclobutrazol (Pac) on fresh and dry weight of shoots and roots of sesame plants. Values given are means of ten replicates.

\begin{tabular}{|l|c|c|c|c|c|c|c|c}
\hline \multirow{2}{*}{$\begin{array}{l}\text { Treatment } \\
(\mathbf{p p m})\end{array}$} & \multicolumn{2}{|c|}{$\begin{array}{c}\text { F.wt. of shoots } \\
\text { (g.) }\end{array}$} & \multicolumn{2}{c|}{$\begin{array}{c}\text { D.wt. of shoots } \\
\text { (g.) }\end{array}$} & \multicolumn{2}{c|}{ F.wt. of roots (g.) } & \multicolumn{2}{c}{$\begin{array}{c}\text { D.wt. of roots } \\
\text { (g.) }\end{array}$} \\
\cline { 2 - 9 } & Stage I & Stage II & Stage I & Stage II & Stage I & Stage II & Stage I & Stage II \\
\hline Control & 13.61 & 86.31 & 1.87 & 19.45 & 1.89 & 11.10 & 0.42 & 3.73 \\
\hline Asc 50 & 19.84 & 131.00 & 2.94 & 26.70 & 3.28 & 15.06 & 0.68 & 4.43 \\
\hline Asc 100 & 7.41 & 93.63 & 1.08 & 19.96 & 1.35 & 11.79 & 0.24 & 4.19 \\
\hline BA 50 & 34.13 & 206.60 & 4.55 & 41.20 & 5.13 & 25.19 & 0.87 & 7.85 \\
\hline BA 100 & 20.51 & 205.36 & 2.77 & 40.91 & 3.32 & 26.31 & 0.53 & 7.57 \\
\hline Pac 25 & 26.72 & 220.88 & 3.46 & 39.05 & 4.29 & 20.08 & 0.65 & 5.33 \\
\hline Pac 50 & 21.18 & 229.25 & 2.95 & 43.26 & 4.66 & 23.62 & 0.90 & 6.98 \\
\hline $\begin{array}{l}\text { LSD } \\
\text { 0.05 }\end{array}$ & $\mathbf{1 . 3 5}$ & $\mathbf{9 . 0 6}$ & $\mathbf{0 . 2 2}$ & $\mathbf{1 . 9 5}$ & $\mathbf{0 . 3 5}$ & $\mathbf{0 . 9 7}$ & $\mathbf{0 . 0 7}$ & $\mathbf{0 . 4 3}$ \\
\hline
\end{tabular}

Table (3): Effect of ascorbic acid (Asc), benzyl adenine (BA) and paclobutrazol (Pac) on chlorophyll and carotenoids contents $(\mathrm{mg} / \mathrm{g}$. F. wt) of sesame plants. Values given are means of three replicates.

\begin{tabular}{|l|c|c|c|c|c|c|c|c|}
\hline \multirow{2}{*}{$\begin{array}{l}\text { Treatment } \\
(\mathbf{p p m})\end{array}$} & \multicolumn{2}{|c|}{ Chlorophyll a } & \multicolumn{2}{c|}{ Chlorophyll b } & \multicolumn{2}{c|}{ Chlorophyll a+b } & \multicolumn{2}{c|}{ Carotenoids } \\
\cline { 2 - 10 } & Stage I & Stage II & Stage I & Stage II & Stage I & Stage II & Stage I & Stage II \\
\hline Control & 6.24 & 9.47 & 2.65 & 3.13 & 8.89 & 12.61 & 2.74 & 4.28 \\
\hline Asc 50 & 4.18 & 9.19 & 1.79 & 2.84 & 5.98 & 12.03 & 1.86 & 4.50 \\
\hline Asc 100 & 3.97 & 6.03 & 1.87 & 2.38 & 5.84 & 8.41 & 1.22 & 3.01 \\
\hline BA 50 & 5.48 & 7.24 & 2.38 & 2.32 & 7.86 & 9.56 & 2.24 & 3.61 \\
\hline BA 100 & 4.31 & 9.51 & 2.21 & 2.83 & 6.52 & 12.34 & 1.71 & 4.69 \\
\hline Pac 25 & 5.89 & 10.91 & 2.67 & 3.67 & 8.56 & 14.58 & 2.52 & 4.94 \\
\hline Pac 50 & 8.43 & 9.70 & 3.98 & 3.09 & 12.41 & 12.79 & 3.28 & 4.71 \\
\hline LSD at 0.05 & $\mathbf{0 . 8 1}$ & $\mathbf{0 . 0 4 2}$ & $\mathbf{0 . 0 9}$ & $\mathbf{0 . 0 6}$ & $\mathbf{1 . 3 1}$ & $\mathbf{0 . 0 8}$ & $\mathbf{0 . 0 5 4}$ & $\mathbf{0 . 0 3 2}$ \\
\hline
\end{tabular}


Table (4): Effect of ascorbic acid (Asc), benzyl adenine (BA) and paclobutrazol(Pac) on total water soluble carbohydrates contents $(\mathrm{mg} / \mathrm{g}$. dry weight) of sesame plants. Values given are means of three replicates.

\begin{tabular}{|c|c|c|c|c|c|}
\hline \hline \multirow{2}{*}{$\begin{array}{l}\text { Treatment } \\
\text { (ppm) }\end{array}$} & \multicolumn{2}{|c|}{ Roots } & \multicolumn{2}{c|}{ Shoots } & \multirow{2}{*}{ Fruits } \\
\cline { 2 - 5 } & Stage I & Stage II & Stage I & Stage II & \\
\hline Control & 62.03 & 64.41 & 58.66 & 78.51 & 102.18 \\
\hline Asc 50 & 83.30 & 77.36 & 56.74 & 72.15 & 155.59 \\
\hline Asc 100 & 76.82 & 77.13 & 53.64 & 100.27 & 150.31 \\
\hline BA 50 & 74.67 & 55.13 & 110.11 & 70.73 & 112.91 \\
\hline BA 100 & 78.08 & 86.89 & 73.45 & 73.68 & 154.41 \\
\hline Pac 25 & 75.40 & 92.87 & 110.38 & 131.23 & 61.03 \\
\hline Pac 50 & 168.97 & 117.51 & 156.55 & 134.41 & 139.23 \\
\hline LSD at 0.05 & $\mathbf{7 . 6 6}$ & $\mathbf{7 . 2 3}$ & $\mathbf{3 . 3 9}$ & $\mathbf{1 . 8 2}$ & $\mathbf{4 . 4 4}$ \\
\hline
\end{tabular}

Table (5): Effect of ascorbic acid (Asc), benzyl adenine (BA) and paclobutrazole (Pac) on soluble proteins contents $(\mathrm{mg} / \mathrm{g}$. dry weight)of sesame plants. Values given are means of three replicates.

\begin{tabular}{|c|c|c|c|c|c|}
\hline \multirow{2}{*}{$\begin{array}{l}\text { Treatment } \\
\text { (ppm) }\end{array}$} & \multicolumn{2}{|c|}{ Roots } & \multicolumn{2}{c|}{ Shoots } & \multirow{2}{*}{ Fruits } \\
\cline { 2 - 5 } & Stage I & Stage II & Stage I & Stage II & \\
\hline Control & 107.22 & 120.29 & 98.52 & 90.60 & 140.20 \\
\hline AA 50 & 107.59 & 96.83 & 122.87 & 102.63 & 124.61 \\
\hline AA 100 & 103.84 & 103.38 & 138.89 & 95.16 & 124.34 \\
\hline BA 50 & 95.36 & 97.10 & 112.86 & 105.04 & 124.37 \\
\hline BA 100 & 86.85 & 105.64 & 118.54 & 137.81 & 128.26 \\
\hline Pac 25 & 89.56 & 86.31 & 100.24 & 81.69 & 89.69 \\
\hline Pac 50 & 82.58 & 115.62 & 111.27 & 87.17 & 73.59 \\
\hline LSD at 0.05 & $\mathbf{7 . 7 3}$ & $\mathbf{8 . 8 5}$ & $\mathbf{1 1 . 5 2}$ & $\mathbf{8 . 4 6}$ & $\mathbf{7 . 1 9}$ \\
\hline
\end{tabular}

Table (6): Effect of ascorbic acid (Asc), benzyl adenine (BA) and paclobutrazol (Pac) on activities of proteases, amylases and lipases enzymes $(\mathrm{mg} / \mathrm{g}$. dry weight equivalent) of sesame plants. Values given are means of three replicates.

\begin{tabular}{|c|c|c|c|c|c|c|}
\hline \multirow{2}{*}{$\begin{array}{l}\text { Treatment } \\
\text { (ppm) }\end{array}$} & \multicolumn{2}{|c|}{ Proteases } & \multicolumn{2}{|c|}{ Amylases } & \multicolumn{2}{|c|}{ Lipases } \\
\hline & Stage I & Stage II & Stage I & Stage II & Stage I & Stage II \\
\hline Control & 1.32 & 2.22 & 1.63 & 1.47 & 14.06 & 7.03 \\
\hline Asc 50 & 1.44 & 2.29 & 1.38 & 1.73 & 3.51 & 11.72 \\
\hline Asc 100 & 1.55 & 2.36 & 1.72 & 1.80 & 2.34 & 24.60 \\
\hline BA 50 & 1.51 & 2.11 & 0.75 & 1.84 & 4.69 & 2.34 \\
\hline BA 100 & 1.63 & 1.60 & 1.78 & 1.31 & 16.40 & 11.72 \\
\hline Pac 25 & 1.86 & 1.53 & 1.72 & 1.98 & 4.69 & 4.69 \\
\hline Pac 50 & 1.73 & 1.60 & 1.55 & 1.70 & 2.34 & 7.03 \\
\hline LSD at 0.05 & 0.031 & 0.026 & 0.057 & 0.06 & 1.65 & 2.13 \\
\hline
\end{tabular}


Table (7): Effect of ascorbic acid (Asc), benzyl adenine (BA) and paclobutrazol (Pac) on yield components of sesame plants. Values given are means of ten replicates.

\begin{tabular}{|l|c|c|c|}
\hline Treatment (p.p.m.) & No.of fruits/plant & Weight of fruits/plant & $\begin{array}{c}\text { Weight of } 1000 \\
\text { seeds }(\mathrm{g})\end{array}$ \\
\hline Control & 30.40 & 10.49 & 3.16 \\
\hline AA. 50 & 45.60 & 11.49 & 3.71 \\
\hline AA. 100 & 2.80 & 10.89 & 3.48 \\
\hline BA 50 & 68.80 & 19.95 & 3.81 \\
\hline BA 100 & 59.60 & 18.60 & 3.64 \\
\hline PAC 25 & 81.20 & 24.93 & 4.32 \\
\hline PAC 50 & 90.40 & 29.51 & 4.10 \\
\hline LSD at 0.05 & $\mathbf{3 . 8}$ & $\mathbf{1 . 1 7}$ & $\mathbf{0 . 0 3}$ \\
\hline
\end{tabular}

Table (8): Effect of ascorbic acid (Asc), benzyl adenine (BA) and paclobutrazol(Pac) on soluble carbohydrates, proteins and total lipids of the seed yield of sesame plants. Values given are means of three replicates.

\begin{tabular}{|l|c|c|c|}
\hline \multicolumn{1}{|c|}{ Treatment $(\mathrm{ppm})$} & Carbohydrates & Proteins & Total lipids (\%) \\
\hline Control & 41.91 & 110.70 & 42.2 \\
\hline AA. 50 & 49.48 & 117.26 & 54.8 \\
\hline AA 100 & 42.28 & 93.64 & 53.54 \\
\hline BA. 50 & 44.38 & 94.68 & 32.82 \\
\hline BA 100 & 48.34 & 116.93 & 45.87 \\
\hline PAC 25 & 43.87 & 80.49 & 47.43 \\
\hline PAC 50 & 47.13 & 92.75 & 49.65 \\
\hline LSD at 0.05 & $\mathbf{0 . 5 4}$ & $\mathbf{5 . 6 8}$ & $\mathbf{1 . 6 5}$ \\
\hline
\end{tabular}

\section{References}

1. Abd El-Aziz, N. G.; Mazher, A. A. M. and El-Habba, E. (2006): Effect of foliar spraying with ascorbic acid on growth and chemical constituents of Khya senegalensis grown under salt condition. American-Eurasian J.Agric.\& Environ .Sci., 1(3): 207-214.

2. Abdel-Halim, S.M., (1995): Effect of some vitamins as growth regulators on growth, yield and endogenous hormones of tomato plants during winter. Egypt. J. of Appl. Sci., 10(12) 322-334.

3. Abdul- Jaleel, C.; Manivannan, P.; Sankar, B.; Kishorekumar, A.; Sankari, S. and Panneerselvam, R. (2007): Paclobutrazol enhances photosynthesis and ajmalicine production in Catharanthus roseus. Process Biochemistry. 42: 1566-1570

4. Abed, A.M. (2001): Growth and yield of cotton plant as affected by pix, BA, Prep and 
their combinations. Annals of Agric. Sci., Moshtohor. Vol. 39(3):1551-1569.

5. Afifi, W.M.; Ahmed, M.I.; Moussa, Z.A. and Abd El-Hamid, M.F. (1986): Effect of gamma irradiation and $\mathrm{GA}_{3}$ on amylase activity of pea seedlings. Ann. Agric. Sci., Moshtohor. Vol. 24(4):2047-2057.

6. Amin, A.A. (2007): Physiological response of two hybrids of yellow maize to foliar application of atonic and paclobutrazol. J. Agric. Sci., Mansoura Univ., 32(4): 2527-2541.

7. Binns, A.N. (1994): Cytokinin accumulation and action : biochemical. Ann. Rev. Plant Physiol. Plant Mol. Biol. 45:175-196.

8. Chaturvedi, A. K.; Vashistha1, R. K.; Prasad, P. and Nautiyal, M. C. (2009): Influence of Foliar Spray with Paclobutrazol and Ethepon on Growth and Photosynthetic Behavior of Saussurea costus (Falc.) Lipsch. - An Endangered Medicinal and Aromatic Herb. Nature and Science, 2009; 7(8)

9. Dowiadar, S.M.; Kassam, W.A. and Mohsen, A.A. (1996): Effect of benzyl adenine on pigmentation, carbohydrate content and activity of amytase in Raphanus sativus seedlings. Egypt J. Physiol., 20, No. 1-2, pp. 101-108.

10. Eid, R. A., Taha, S. L., and Ibrahim, M.M. S. (2010): Physiological properties studies on essential oil of Jasminum grandiflorum L. as affected by some vitamins. Ozean Journal of Applied Sciences 3(1): 87-96.

11. El-Abagy, H.M.H.; Amin A.A.; Rashad El-Sh. M. and Hassanein, M.S. (2003): Physiological response of some faba bean cultivars to foliar spray with benzyl adenine. Egypt. J. Appl. Sci.; 18(11B):563-579.

12. Elgayar, S.H. (2004): Effect of pendimethalin (stomp) and benzyl adenine (BA) on associated weeds, growth, yield and chemical composition of soybean plants at Nobarya. J. Agric. Sci. Mansoura Univ., 29(7), July, 3925-3934.

13. El-Maadawy, E.I.; Mansour, H.A. and Mostafa, H.G. (2006): Response of annual flowering plants to manual pinching and benzyl adenine treatments : 1- Pot marigold (Calendula afficinalis L.) plants. J. Agric. Sci., Mansoura Univ., 31(7):4463-4483.

14. Elwan, S.H.; El-Naggar, M.R. and Ammar, M.S. (1976): Characteristics of lipases in the growth filtrate dialysate of Bacillus stearothermophilus grown at $55^{\circ} \mathrm{C}$ using a tribution cup. Plate assay. Bull. Fac. Sci. Riyadh Univ. "in press" (c.f. Ouda, A.E.S, 1977 : studies on certain thermophilic bacteria. Ph.D. Thesis, Bot. Dep., Fac. Sci., Al-Azhar Univ., Cairo, Egypt.

15. Ewais, A, E. (2003): Physiological responses of broad bean plamts to cadmium and lead and their antagonism by the antioxidant ascorbic acid and calcium. Journal of the Faculty of Education.No. 28.: 207-224.

16. Farahat, M.M.; Hebba, E.L. and Rashad, E. M. (2002): Physiological response of fennel to tryptophan, naphthalene acetic acid and benzyl adenine treatments in sandy soil. Egypt. J. Appl. Sci. 17(11) 624-633.

17. Farahat, M.M.; Ibrahim, S.M.M.; Taha, L.S. and El-Quesni, F.E.M. (2007): Response 
vegetative growth and some chemical constituents of Cupressus sempervirens L. to foliar application of ascorbic acid and zinc at Nubaria. World J.of Agric Sci., 3(3): 282-288.

18. Guenther, E. (1972): The essential oils. Vol. 1, Robert, E.; Kreiger Publishing Co. Huntington, New York.

19. Hamza, A.M.; Abd El-Kafie O.M. and Mohei, A.M. (2007): Improving growth quality of Pelargonium zonale L. by using some growth retardants. J. Agric. Sci., Mansoura Univ., 32(10):8399-8411.

20. Hare, P.D.; Cress, W.A. and Van Stadem, J. (1997): The involvement of cytokinin in plant responses to environmental stress. Plant Growth Regul., 23:79-103.

21. Husein, E.A. (1993): Studies on the effect of water stress and the treatment with some growth substances on Datura stramonium. M.Sc. Thesis, Fac. of Sci., Al-Azhar Univ., Cairo, Egypt.

22. Ibrahim, S.I.; Sanaa, A.M.Z.; El-Shamey, I.Z. and Eisa, S.S. (2001): The effect of kinetin (kin) or thidiazuron (TDZ) in combinations with ABA or JA on regulating growth, yield and seed lipids composition of sunflower (Helianthus annuus L.). Annals Agric. Sci. (Cairo) 46(2):465-483.

23. Ibrahim, S.M; Taha, L.S.; Farahat, M.M. (2010): Vegetative Growth and Chemical Constituents of Croton Plants as Affected by Foliar Application of Benzyl adenine and Gibberellic Acid J Amer.Sci 6: 126- 130.Lichtenthaler, HK. (1981): Photosynthesis IV. Philadelphia. Balaban Internat Science Service. p. 273-285.

24. Lolaei, A.; Kaviani, B.; Raad, M. K.; Rezaei, M. A. and Maghsoudi, M. (2012): Effect of Paclobutrazol and Salinity on Vegetative and Sexual Growth and Fruit Quality of Strawberry (Fragaria $\times$ Ananassa Duch. cv. Selva). Annals of Biological Research, 3 (10):4663-4667

25. Lowry, O.H.; Rosebrough, N.J.; Furr, A.I. and Randall, R.J. (1951): Protein measurement with folin phenol reagents. J. Biol. Chem. 193:265-275.

26. Lichtenthaler, HK. (1981): Photosynthesis IV. Philadelphia. Balaban Internat Science Service. p. 273-285.

27. Mazher, A A.M.; Zaghloul, S. M. Mahmoud, S. A.; and Siam, H. S. (2011): Stimulatory Effect of Kinetin, Ascorbic acid and Glutamic Acid on Growth and Chemical Constituents of Codiaeum variegatum L. Plants. American-Eurasian J. Agric. \& Environ. Sci., 10 (3): 318-323.

28. Mazrou, M.M. (1992): The growth and tropine alkaloids distribution on the different organs of Datura innoxia, Mill Plants on relation to benzyl adenine (BA) application. Menofiya. J. Agric. Res. 17(4):1971-1983.

29. Menesi, F.A.; Khalafalla, M.M. and Kandeel, Y. (1994): Effect of some growth regulators and calcium chloride on Tagets erecta, L., Zinnia elegan, L. and Celalosia argenata, L. plants. The First Conf. of Ornamental Hort. (2) 418-425.

30. Nassar, H.H.; Barakat, M.A.; El-Masry, T.A. and Osman, A.S. (2001): Effect of 
potassium fertilization and paclobutrazol foliar application on regulative growth and chemical composition of sweet pepper. Egypt J. Hort. 28(1):113-129.

31. Nzikou, J.M.; Matos, L.; Bouanga-Kalou, G.; Ndangui ,C.B.; Pambou-Tobi, N.P.G.; Kimbonguila, A.; Silou ,Th.; Linder, M. and Desobry, S.(2009): Chemical Composition on the Seeds and Oil of Sesame (Sesamum indicum L.) Grown in Congo-Brazzavill. Advance Journal of Food Science and Technology 1(1): 6-11.

32. Ong, P.S. and Gaucher, G.M. (1972): Protease production by thermophillic fungi. Can. J. Microbiology, 19:129-133.

33. Prusakova, L.D.; Chizhova, S.I. and Pavlova, V.V. (2004): Assessment of triazole growth - retarding activity in an $\alpha$-amylase bioassay using spring Barley endosperm. Russian J. of Plant Physiology, Vol. 51, No. 4, pp. 563-567. Translated from Fiziologiya rastenii, Vol. 51, No. 4, 2004, pp. 626-630.

34. Rafique, N.; Raza, S. H.; Qasim, M. and abd Iqbal, N. (2011): Pre-sowing application of ascorbhc acid and salicylic acid to seed of pnmpkin and seedling to salt. Pak. J. Bot., 43(6): 2677-2682.

35. Reda F., Baroty, G.S.A.; Talaat, I.M.; Abdel-Rahim, I.A. and Ayad, H.S. (2007):Effect of some growth regulators and vitamins on essential oil, phenolic contents and activity of oxidoreductase enzymes of Thymus vukgaris L. World Journal of Agricultural Sciences 3 (5): 630-638.

36. Shalaby, M.A.F.; Amin A.A.; Ahmed, M.A. and Rashad, El-Sh.M. (2005): Physiological response of two sesame (Sesamum indicum L.) cultivars to some growth retardants in newly cultivated sandy lands. Egypt. J. of Appl. Sci., 20(12):210-228.

37. Shehata, M.M., El-Khawas, S.A., (2003): Effect of two biofertilizers on growth parameters, yield characters, nitrogenous components, nucleic acids content, minerals, oil content, protein profiles and DNA banding pattern of sunflower (Helianthus annus L. cv. Vedock) yield. Pak. J. Biol. Sci. 6, 1257-1268.

38. Snedecor, G.M. and Cochran, W.G. (1982): Statistical methods 7 edition, lowa state Univ., Press, Ames., thlowa U.S.A., pp: 325-330.

39. Talaat, I.M. and Youssef, A.A. (1998): Response of roselle plants (Hibiscus sabdariffa L.) to some growth regulating substances. Egypt J. Physiol. Sci., 22, No. 3, pp. 327-338.

40. Umbriet, W.W.; R.H. Burris, J.F.; stauffer, P.P.;Cohen, W.J.; Johsen, L. G.A.; page, V.R.; and W.C. Schneicter, 1969. Manometric techniques, manual describing methods applicable to the studs of tissue metabolism. Burgess publishing Co., U.S.A., pp: 239.

41. Vernon, L.P. and Seely, G.R. (1966): The chlorophylls. Acad. Press, New York, London.

42. Vijay L. and Laxmi, V. (2001): Effect of benzyl adenine on dry matter distribution and yield of mungbean under different source sink relationship. Indian J. of Pulses; Res. 14(2):138-140.

43. Vasudevan, S.N.; Virupakshappa, K.; Bhaskar, S. and Udayakumar, M. (1996): Influence of growth regulators on some productive parameters and oil content sunflower (Helianthus annuus L.). Indian J. Plant Physiol. 1:277-280. 
44. Wanas, A.L. (2007): Response of faba bean (Vicia faba, L.) plants to seed-treating with garlic extract, salicylic acid and paclobutrazol. J. Agric. Sci. Mansoura Univ., 32(2):971990.

45. Weiss E. A. (1971): Castor, sesame, and safflower. Barnes and Noble, Inc., New York.

46. Youssef, A.A.; Mahgoub, M.H. and Talat, I.M. (2004a): Physiological and biological aspects of Matthiola incana plants under the effect of putrescine and kinetin treatments. Egypt J. Appl. Sci.; 19(9B) 492-510.

47. Yousif A. A.; Sarfaraz F. A. and Hadar S. F. (2012): Effect of sucrose and ascorbic acid concentrations on vase life of snapdragon (Antirrhinum Majus L.) cut flowers. Int. J. Pure Appl. Sci. Technol., 13(2): 32-41.

48. Zedan, H.M. (2000): Effect of tryptophan and paclobutrazol on carawy (Coriandrum sativum L.) plants. M.Sc. Thesis, Fac. Agric. Cairo Univ. Egypt.

49. Zhang, M.; Duan, L.; Zhai, J.; Li, X.; Tian, B.; Wang, Z.; He and Li, Z. (2006): Effect of plant growth regulators on water deficit - induced yield loss in soybean. Australian Agron. Conf. 10-15. 


\section{الملخص العربي}

أجريت تجربة حقلية لدراسة تأثنر الرش الورقي من حامض الاسكوربيك (100,50

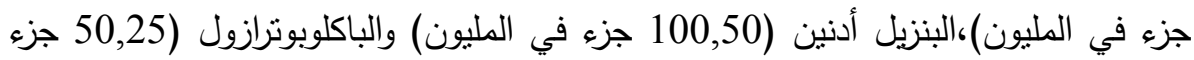
في المليون) على النمو والمحصول لنبات السمسم. كانت جميع التركيزات المستخدمة فعالة في تتشيط أطوال المجموع الخضري والجذري وعدد الأوراق لكل نبات. أظهرت النتائج التي تم الحصول عليها أيضا أن استخدام حمض الاسكوربيك عند 50 جزء في المليون أو البنزيل

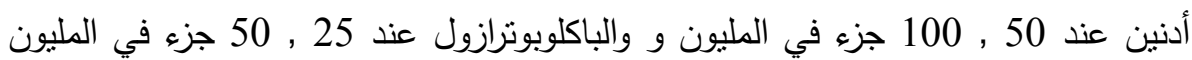

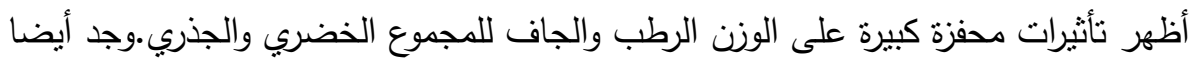
أن الباكلوبوترازول أكثر فعالية من المعاملات الأخرى في تتشيط محتويات الكلوروفيل

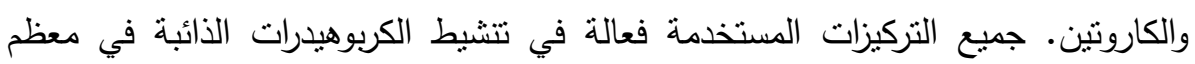
أجزاء النباتات المعاملة وظهر العكس بالنسبة لمحتويات البروتين في الجذور والثمار من فئن فيطن النباتات المعاملة. وسجلت أيضا التغيرات في أنشطة الانزيمات الهحلله للبروتينات والنشويات والدهون. وارتبطت هذه التغيرات مع تحسين جودة المحصول والقيمة الغذائية

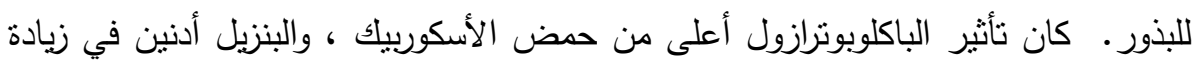

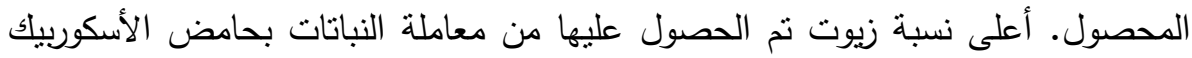

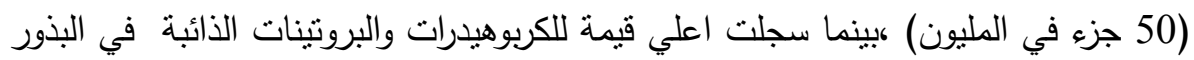

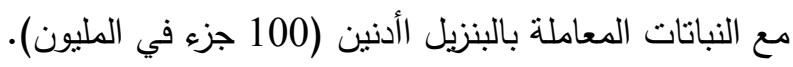


